different aspects of recreational activities for the youths, provision of information on employment opportunities for the youth, and engaging on outreach programmes on prevention of negative consequences of youth violence and engaging in public private partnership initiatives to check the violent activities of the youth. The paper recommended that government at all levels should invest in library development considering its role in socio-economic development of the country.

\section{SOCIO-ECONOMIC PREDICTORS OF YOUTH VIOLENCE IN NIGERIA: LIBRARY INTERVENTION STRATEGIES}

R I Echezona*, C I Ugwu, R E Ozioko Correspondence: Nnamdi Azikiwe Library, University of Nigeria, Nsukka 234, Nigeria

\subsection{6/ip.2010.029215.130}

The paper aimed at developing some library intervention strategies for curbing violence in our society within the context of socio-economic predictors of youth violence. The study adopted a descriptive survey design to explore the violent activities of youths and their socio-economic predictors. The population of the study consisted of librarians and youths in Nigeria Universities drawn from the six geographical zones of the country. Three Universities were randomly selected from each of the six geo-political zones in Nigeria, while the Librarians from these selected Universities were studied (n1=100). A total number of 2700 undergraduates were randomly selected from the three Universities studied ( $\mathrm{n} 2=\mathrm{n} 3=\mathrm{n} 4=900)$. Questionnaire was instruments used for data collection. The findings revealed that youths studied are involved in so many violent activities due largely to frustration. The socio-economic predictors of youth violence include apparent lack of parental control, poor social infrastructure, insufficient academic training, unemployment, poor family living condition and high cost of living. This paper argues that libraries can contribute greatly to curbing of youth violence by embarking on intervention strategies. These strategies include provision of information on 